\title{
SunShot
}

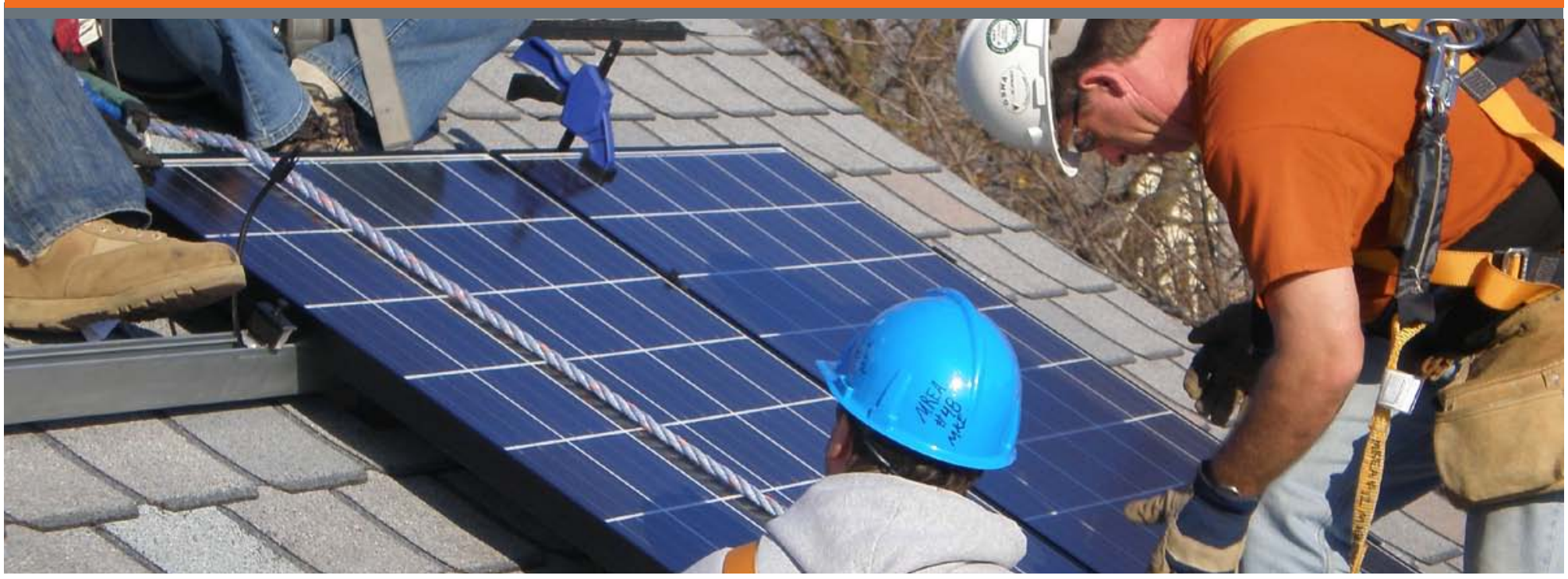

\section{SunShot Prize: America's Most Affordable Rooftop Solar A COMPETITION TO SPUR LOW-COST ROOFTOP SOLAR INSTALLATIONS ACROSS THE NATION}

The first ever SunShot Prize offers $\$ 10$ million in total prize money to teams able to dramatically reduce the price of rooftop solar energy for American families and businesses. This national effort challenges solar businesses across the nation to claim title to the SunShot Prize for America's Most Affordable Rooftop Solar.

The SunShot Prize encourages novel public-private partnerships, original business models, and innovative approaches to installing clean, renewable solar energy. The sustainable business strategies developed by participants will provide transferrable lessons that can be applied nationwide to hasten America's transition to affordable clean energy in a post-subsidy market.

\section{Breaking Barriers}

According to the SunShot Vision Study, the price of a residential photovoltaic (PV) system was about $\$ 6$ per watt (W) in 2010. Achieving an average price of $\$ 2 / \mathrm{W}$ for fully installed PV systems would accelerate clean energy deployment on America's rooftops, providing a clean, secure, affordable energy source. Although breaking this price barrier is an aggressive goal, rapidly declining costs for modules, hardware, and associated fees have made this target feasible.

\section{By the Numbers}

aval cash awards
customers pay
average install price
installations
maximum installed
system capacity
installations have to be located
in U.S. states or territories

The DOE SunShot Initiative is a collaborative national initiative to make solar energy technologies costcompetitive with other forms of energy by reducing the cost of solar energy systems by about $75 \%$ by the end of the decade. Reducing the total installed cost for utility-scale solar electricity to roughly 6 cents per kilowatt-hour without subsidies will result in rapid, largescale adoption of solar electricity across the United States. Reaching this goal will re-establish American technological leadership, improve the nation's energy security, and strengthen U.S. economic competitiveness in the global clean energy race. 


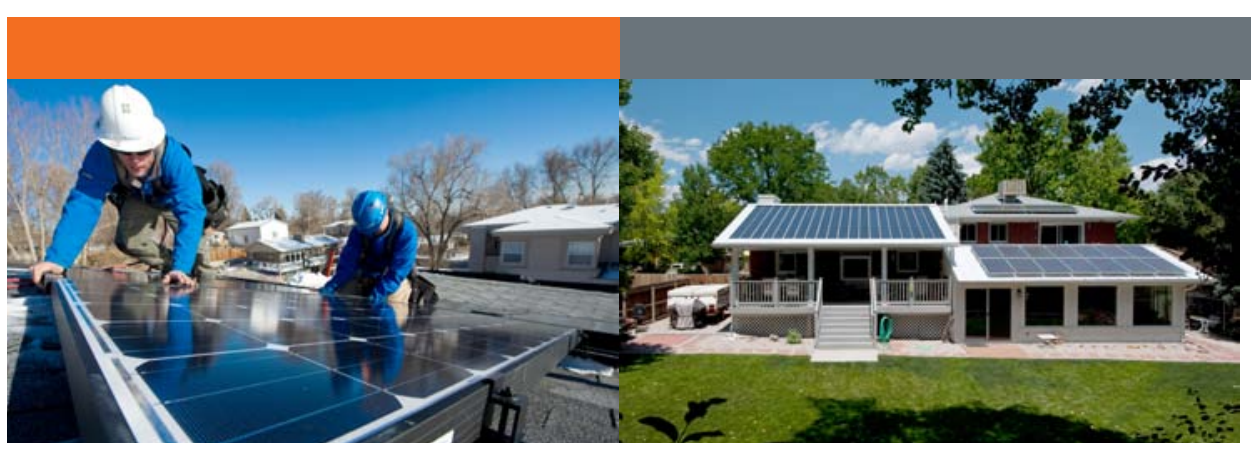

\section{Rewarding Success}

A total of $\$ 10$ million in prize money will be distributed among the first three teams that can install 5,000 small-scale (1-15 kilowatt) rooftop solar systems at an average price of $\$ 2 / \mathrm{W}$ before subsidies. All installations must meet the requirements established by the U.S. Department of Energy, including completion before December 31, 2014.

The first team to successfully meet the program's criteria will win $\$ 7$ million and rights to publicly call themselves the SunShot Prize Winner offering America's Most Affordable Rooftop Solar. The second and third teams to reach this milestone will be designated SunShot Prize Finalists and will be awarded \$2 million and \$1 million, respectively.

\section{For More Information}

eere.energy.gov/solar/sunshot/prize.html

\section{Timeline of Program Deadlines}

Make solar installations more affordable for American families

\section{Demonstrate sustainable business models to break the $\$ 2 / W$ price barrier}

\section{Enable the private sector transition to a post-incentive market}

\section{us ocesermentrof of \\ ENERGY}

energy.gov

DOE/GO-102012-3657 • June 2012

Printed with a renewable-source ink on paper containing at least $50 \%$ wastepaper, including $10 \%$ post consumer waste.
10.31.2014

Registration to Compete Closes

11.30.2014

Pre-Submission

Approvals Close

\section{3}

12.31 .2012

Submissions Open

7.13 .2012

Deadline

2014

12.31.2014

Submissions

Close
8.11.2015 Winner(s) Announcement

\section{Join the Effort}

Beginning on August 1, 2012, participants can register to participate and begin tracking their installations. 